\title{
Recombinant HPV16 E7 assembled into particles induces an immune response and specific tumour protection administered without adjuvant in an animal model
}

Linda Petrone ${ }^{1}$, Maria G Ammendolia ${ }^{2}$, Armando Cesolini ${ }^{1}$, Stefano Caimi ${ }^{3}$, Fabiana Superti ${ }^{2}$, Colomba Giorgi ${ }^{1}$ and Paola Di Bonito ${ }^{1 *}$

\begin{abstract}
Background: The HPV16 E7 protein is both a tumour-specific and a tumour-rejection antigen, the ideal target for developing therapeutic vaccines for the treatment of HPV16-associated cancer and its precursor lesions. E7, which plays a key role in virus-associated carcinogenesis, contains 98 amino acids and has two finger-type structures which bind a $\mathrm{Zn}^{++}$ion. The ability of an Escherichia coli-produced E7-preparation, assembled into particles, to induce protective immunity against a HPV16-related tumour in the TC-1-C57BL/6 mouse tumour model, was evaluated.
\end{abstract}

Methods: E7 was expressed in E. coli, purified via a one-step denaturing protocol and prepared as a soluble suspension state after dialysis in native buffer. The presence in the E7 preparation of particulate forms was analysed by non-reducing SDS-PAGE and negative staining electron microscopy (EM). The $\mathrm{Zn}^{++}$ion content was analysed by mass-spectrometry. Ten $\mu \mathrm{g}$ of protein per mouse was administered to groups of animals, once, twice or three times without adjuvant. The E7-specific humoral response was monitored in mice sera using an E7-based ELISA while the cell-mediated immune response was analysed in mice splenocytes with lymphoproliferation and IFN- $\gamma$ ELISPOT assays. The E7 immunized mice were challenged with TC-1 tumour cells and the tumour growth monitored for two months.

Results: In western blot analysis E7 appears in multimers and high molecular mass oligomers. The EM micrographs show the protein dispersed as aggregates of different shape and size. The protein appears clustered in micro-, nano-aggregates, and structured particles. Mice immunised with this protein preparation show a significant E7specific humoral and cell-mediated immune response of mixed Th1/Th2 type. The mice are fully protected from the tumour growth after vaccination with three E7-doses of $10 \mu \mathrm{g}$ without any added adjuvant.

Conclusions: This report shows that a particulate form of HPV16 E7 is able to induce, without adjuvant, an E7specific tumour protection in C57BL/6 mice. The protective immunity is sustained by both humoral and cellmediated immune responses. The E. coli-derived HPV16 E7 assembled in vitro into micro- and nanoparticles represents not only a good substrate for antigen-presenting cell uptake and processing, but also a cost-effective means for the production of a new generation of HPV subunit vaccines.

\footnotetext{
* Correspondence: paola.dibonito@iss.it

'Department of Infectious Parasitic and Immune-mediated Diseases, Istituto

Superiore di Sanità, Viale Regina Elena 299, 00161 Rome, Italy

Full list of author information is available at the end of the article
} 


\section{Background}

Human Papillomavirus type 16 (HPV16) is associated with the development of benign and malignant lesions of the oral and genital tract [1]. The oncogenic potential of HPV16 is mainly ascribed to the viral oncoprotein E7, which has been shown to interact with a variety of cellular proteins. HPV16 E7 is a 98-amino-acid phosphoprotein $(11 \mathrm{kDa})$ that binds the $\mathrm{Zn}^{++}$ion through two Cys-X-X-Cys motifs proposed to be involved in protein oligomerization [2-4]. An ATP-independent chaperone holdase activity was recently detected as the first biochemical activity of HPV16 E7 [5]. E7 is a tumour specific antigen (TSA), the mediator of tumour recognition by the host immune response [6], hence an ideal target for the development of therapeutic vaccines for treating HPV16-associated cancer and its precursor lesions [7-9].

HPV16 E7 has been expressed in various eukaryotic and prokaryotic systems [10-26] since the end of the 80 s. The main objective was to produce and purify E7 in the native form to study both, its molecular structure and its cell transformation activity in vitro. Some of these studies have also shown the ability of E7 to form aggregates when present in high quantities. Electron microscopy micrographs of bacterial-derived E7 aggregates in particles have been shown only by Chinami et al. [20] and Alonso et al. [27]. Bacteria-derived E7 maintains the antigenic properties of the native protein, being recognised by sera from HPV infected subjects and has therefore been used in HPV serology [28-31].

The E7 protein was extensively used in vaccine development. It is a small protein poorly immunogenic (11 $\mathrm{kDa}$ ) hence it was used with immunological adjuvants, protein and gene carriers. Various forms of therapeutic vaccines based on E7 have been developed and tested in animal models. Most of the vaccines induced E7-specific CTLs and were effective in HPV16-related tumour regression in animal models. Nevertheless, only few have reached the clinical trial phase [7-9]. As the HPV16 mouse tumour model [32] had been made available to the research community and was easy to set up, considerable work was done using E7 as antigen to demonstrate the efficacy of various adjuvants, molecular carriers and genetic vectors as inductors or enhancers of $\mathrm{T}$ cell response [9]. E7 has also been, fused to a number of peptides and proteins, even those of HPV16 such as L1, L2 and E6 with the aim to combine HPV prophylactic and therapeutic vaccines [6-9].

Recent progress in elucidating the cross-presentation mechanism and the role of particulate antigens in CTL immunity [33] encouraged us to use the immunogenicity of a bacterial-derived HPV16 E7, in particle form, to explore the possible development of a therapeutic vaccine against HPV16 related tumours.
This paper shows that a bacterial-derived HPV16 E7 assembles in micro- and nanoparticles on dialysis in buffer containing DTT and induces protective immunity against a tumour cell challenge in an HPV16 mouse tumour model. Interestingly, the E7 particles was administered without adjuvant. The protection of mice from tumour growth induced by the E7 particles is mediated by a strong E7-specific humoral and cell mediated immune response.

\section{Methods}

\section{Protein expression and purification}

Freshly streaked bacterial colonies, containing the E7 plasmid [30], were inoculated in $25 \mathrm{ml} \mathrm{LB}$ medium (DIFCO) and grown to saturation overnight $(\mathrm{O} / \mathrm{N})$ at $37^{\circ} \mathrm{C}$. The culture was then inoculated in $500 \mathrm{ml} \mathrm{LB}$, and grown until the culture density reached $\mathrm{OD}_{600}=0.6$. The His-E7 protein was induced by the addition of $1 \mathrm{mM}$ IPTG (A.G. Scientific, Inc) for $3 \mathrm{~h}$. The culture was harvested and centrifuged for $30 \mathrm{~min}$ in a Sorval centrifuge at $6000 \mathrm{rpm}$ in GSA rotor. The bacterial pellet was lysed for $30 \mathrm{~min}$ in a rotator at room temperature $(\mathrm{R} / \mathrm{T})$ in a denaturing buffer (40 ml) containing $8 \mathrm{M}$ urea (MP Biomedicals, Inc), 10 $\mathrm{mM} \mathrm{NaH}_{2} \mathrm{PO}_{4}, 10 \mathrm{mM}$ Tris- $\mathrm{HCl} \mathrm{pH} 8,300 \mathrm{mM} \mathrm{NaCl}, 1$ mM DTT, (Sigma-Aldrich), 1\% Triton-X 114 (SigmaAldrich) and 1\% Triton X-100 (Buffer B mod). To break the DNA, the lysate was sonicated for $60 \mathrm{~min}$ in the pulsed mode (50\% on/off pulse; effective sonication time, $30 \mathrm{~min}$ ) using an ultrasonic processor (Vibra-Cell 400, Sonics). The lysate was clarified in a Sorval centrifuge for $20 \mathrm{~min}$ at $10.000 \mathrm{rpm}$ in a SS34 rotor. The supernatant was incubated for $30 \mathrm{~min}$ with $4 \mathrm{ml}$ of $50 \%$ slurry NiNTA resin (QIAGEN) at RT. To reduce the endotoxin content, the E7-NiNTA agarose suspension was collected in a 50 $\mathrm{ml}$ tube, extensively washed in batch and spun down in a centrifuge at $500 \times \mathrm{g}$. The E7-NiNTA was sequentially washed in Buffer $\mathrm{B}$ ( $\mathrm{pH} 8$, without detergents) containing $10 \%$ glycerol $(100 \mathrm{ml}), 20 \%$ ethanol $(100 \mathrm{ml})$ and $60 \%$ isopropanol $(200 \mathrm{ml})$. The isopropanol washes were alternated with cold $10 \mathrm{mM}$ Tris- $\mathrm{HCl}$ washes $(200 \mathrm{ml})$ [34]. The last sequential washes were performed using $500 \mathrm{ml}$ Buffer C ( $8 \mathrm{M}$ urea, $10 \mathrm{mM} \mathrm{NaH} \mathrm{PO}_{4}, 10 \mathrm{mM}$ Tris- $\mathrm{HCl}$ $\mathrm{pH}$ 6.3). The protein was eluted by gravity-flow in several $2 \mathrm{ml}$ fractions from packed E7-Ni-NTA using $1 \mathrm{M}$ Imidazole (Sigma-Aldrich) in Buffer B. After an analytical Coomassie stained SDS-PAGE, the fractions containing E7 were collected and the protein was subjected to 2 step-dialysis at $4^{\circ} \mathrm{C}$ in native buffers. The first step was performed in $2 \mathrm{~L}$ of buffer containing $25 \mathrm{mM}$ Tris, $50 \mathrm{mM} \mathrm{NaCl} \mathrm{pH}$ $7.5(\mathrm{TN})$ in presence of $1 \mathrm{mM}$ DTT and the second step was performed in $2 \mathrm{~L}$ of TN buffer only. E7 was concentrated in a centrifugal filter device up to a final concentration of $2 \mathrm{mg} / \mathrm{ml}$. All the reagents were ultrapure grade. The E7 protein yield was $20 \mathrm{mg} / \mathrm{l}$ of medium culture. The 
protein was quantified by standard methods (Protein BC assay, BIORAD); its purity and identity were monitored by SDS-PAGE followed by Coomassie brilliant blue staining and western blotting (30). The endotoxin contamination was as low as $0.5 \mathrm{EU} / \mathrm{mg}$ protein as monitored by LAL assay (QCL-1000, Lonza). The presence of E7 particles was monitored by negative stain EM.

\section{SDS-PAGE and Western Blot analysis}

Protein samples were separated in $12.5 \%$ polyacrylamide gels in Leammli Tris-Glycine buffer and blotted into an Immobilon-P membrane. In a non-reducing gel, the protein samples were denatured in SDS-loading buffer [30] without $\beta$-mercapto-ethanol. The protein was identified by Western blot using both commercial monoclonal and in-house prepared polyclonal anti-E7 antibodies [30]. A peroxidase-conjugate rabbit anti-mouse IgG ( $\mathrm{H}$ + L) (Sigma-Aldrich) was used as secondary antibody. The immune complexes were revealed with a chemiluminescence substrate (PIERCE).

\section{Electron Microscopy Analysis}

$10 \mu \mathrm{l}$ samples of the E7 preparation $(2 \mathrm{mg} / \mathrm{ml})$ were adsorbed for 1 min onto Formvar-coated copper grids, then rinsed briefly with water and negatively stained with $2 \%$ filtered aqueous sodium phosphotungstate adjusted to $\mathrm{pH}$ 7.0. Negatively stained preparations were observed with a Philips $208 \mathrm{~S}$ transmission electron microscope at $80 \mathrm{kV}$.

\section{Zn analysis}

Three samples of different E7 preparations and, as a control, three samples of Glutathione-S-transferase (GST) were analysed for their content of ${ }^{66} \mathrm{Zn}$ and ${ }^{68} \mathrm{Zn}$ analytical masses. The GST protein was produced in pGEX-2T transformed E. coli and purified by glutathione affinity chromatography (PIERCE). Measurements were performed by means of High Resolution Inductively Coupled Plasma-Mass Spectrometry (HRICP-MS), using an Element2 apparatus (Thermo-Finnigan, Bremen, Germany). HR-ICP-MS is a well established and powerful analytical technique for the determination of trace and ultra-trace elements in biological samples. The calibration of the method was performed by the adoption of the standard addition mode: diluted single-element standards were added to the analytical solutions. To compensate for instrumental drifts and matrix effects, indium was added to each sample as an internal standard.

\section{Mice immunization and tumour protection assay}

6-8 week-old female C57BL/6 mice were purchased from Charles River Laboratories and maintained under pathogen-free conditions for one week before the experiment. The animal care and the experiments followed the European Directive 86/609 EEC. The protocol of animal use was evaluated by the Service for Biotechnology Animal Welfare of the Istituto Superiore di Sanità, and approved by the Italian Ministry of Health. Three groups of mice (14 per group) were inoculated subcutaneously with 1, 2 or 3 doses of $10 \mu \mathrm{g}$ E7 respectively, at 1 week intervals. A fourth mouse group was inoculated with a saline solution and used as a control (naïve). Two weeks after the last immunization, 4 mice of each group were sacrificed to analyse the immune response and 10 mice were inoculated subcutaneously with $1 \times 10^{5} \mathrm{TC}-1$ cells/mouse, as described [35]. The TC-1 cells were grown in complete medium with 0.4 $\mathrm{mg} / \mathrm{ml} \mathrm{G} 418$. Cells at 50\% confluence were harvested, counted and rinsed in Hank's medium at $1 \times 10^{6}$ cells/ $\mathrm{ml}$ for the injection in mice. Tumour growth was monitored by visual inspection and palpation once a week for 2 months. The experiment was performed twice.

\section{Lymphoproliferation and IFN $\gamma$-ELISPOT assays}

Splenocytes from mice of the same immunization group were pooled and enriched in $\mathrm{CD} 4^{+}$and $\mathrm{CD} 8^{+}$cells using the Dynal Mouse $\mathrm{T}$ cell Negative isolation kit (Invitrogen). Cells were cultured in RPMI 1640 (Lonza) supplemented with $10 \%$ FCS, $1 \%$ penicillin/streptomycin, $2 \mathrm{mM}$ glutamine, $1 \mathrm{mM}$ pyruvate and $1 \%$ nonessential amino acids (Lonza) (complete RPMI). To assess cell proliferation, the splenocyte pools $\left(2 \times 10^{5}\right.$ cells/well, in triplicate) were stimulated for five days in the presence of $5 \mu \mathrm{g} / \mathrm{ml}$ of two 8- and 9-mer E7 peptides, DLYCYEQL (aa 21-28) and RAHYNIVTF (aa 4957 ), already known to efficiently bind the $\mathrm{H}-2 \mathrm{~K}^{\mathrm{b}}$ complex of C57 Black/6 mice [36]. On day 6, the cells were pulsed with $0.5 \mu \mathrm{Ci}\left[{ }^{3} \mathrm{H}\right]$ thymidine per well and incubated for $18 \mathrm{~h}$. The cells were then harvested onto filters using an automatic harvester and counted in a Beta Counter (Wallac). The results were expressed in stimulation index (SI), calculated by dividing the mean counts per minute (cpm) of cells exposed to the E7 peptides by the mean cpm of cells incubated only with medium. The IFN- $\gamma$ ELISPOT assay was performed using commercially available reagents (Mabtech AB). T-cell enriched splenocytes were seeded in triplicate $\left(5 \times 10^{5}\right.$ cells per well) in $200 \mu \mathrm{l}$ complete medium with the E7 stimulator peptides. After $18 \mathrm{~h}$ at $37^{\circ} \mathrm{C}$ in a humidified $5 \% \mathrm{CO}_{2}$ incubator, the plates were analysed for the presence of IFN- $\gamma$ as described in [35].

\section{Antibody assay}

The sera from each group of immunized mice were pooled and analysed. To determine the anti-E7 specific IgG titre the sera pools were serially diluted (two-fold) and assayed by ELISA [30]. The end-point dilution 
corresponded to an OD absorbance $<0.1$ at $450 \mathrm{~nm}$. Sera pools diluted 1:100 were used to analyse the anti-E7 IgM, IgA and the IgG isotypes (IgG1, IgG2b, IgG2c and IgG3). Antigen-antibody complexes were detected using the following HRP-secondary antibodies (Sigma-Aldrich): rabbit anti-mouse $\operatorname{IgG}(\mathrm{H}+\mathrm{L})$, goat anti-mouse $\operatorname{IgM}(\mu$-chain), goat anti-mouse IgA ( $\alpha$-specific), goat anti-mouse IgG1, IgG2b, IgG3, IgG2c. HRP activity was revealed using tetramethyl benzidine substrate (TMB) in the presence of $\mathrm{H}_{2} \mathrm{O}_{2}$. After $30 \mathrm{~min}$ at $\mathrm{RT}$, the enzymatic reaction was stopped by adding $50 \mu \mathrm{l}$ of $1 \mathrm{M}$ sulphuric acid/well. Washing steps were done with $400 \mu \mathrm{l} /$ well of PBS containing $0.05 \%$ Tween-20 in an automatic washer.

\section{Statistical analysis}

Significance analysis was performed using the Student $t$ test for unpaired data. Differences were considered significant if $P<0.05$.

\section{Results}

\section{Analysis of the E7 preparation}

The E7 protein was expressed in E. coli with a $[\mathrm{His}]_{6}$ tag and purified via a one-step denaturing protocol until a high level of homogeneity and low endotoxin content were achieved $[30,34]$. The protein was prepared in a soluble suspension state by dialysis in Tris buffer and then analysed by western blotting in reducing and nonreducing SDS-PAGE. In the reducing gel, the E7 protein appears in monomeric form (Figure 1, lane 1). In nonreducing gels, based on the analysis of the molecular mass marker, E7 appears in forms consistent with the mass of monomer, dimer, trimer, tetramer, octamer and higher oligomers, suggesting that, in these conditions, the E7 monomer is the oligomerization unit (lane 2).

Preparations of purified E7 were analysed by negative staining EM. Figure 2 shows representative EM micrographs of the E7 preparation samples. The protein appears dispersed on the grid as aggregates of different shape and size (panel A). The protein appears clustered in compact-looking spheroidal microaggregates, the majority ranging between 100 and $200 \mathrm{~nm}$ in size (panel B). In these same samples, E7 also appears assembled in structured particles that seem to derive from the aggregation of smaller particles (panel C). These particles resemble the previously described E7 oligomers [27]. A semi-quantitative analysis by EM counts of micro and nano-sized particles, ranging between $45-200 \mathrm{~nm}$, indicates that E7-aggregates are in the order of $10^{5}$ particles/ml (not shown). The E7 preparations were also subjected to EM immunolabelling but neither commercial anti-E7 monoclonal nor in-house prepared polyclonal antibodies [30] revealed any significant reaction, suggesting that these antibodies were unsuitable for the EM observation of E7-particles (data not shown).

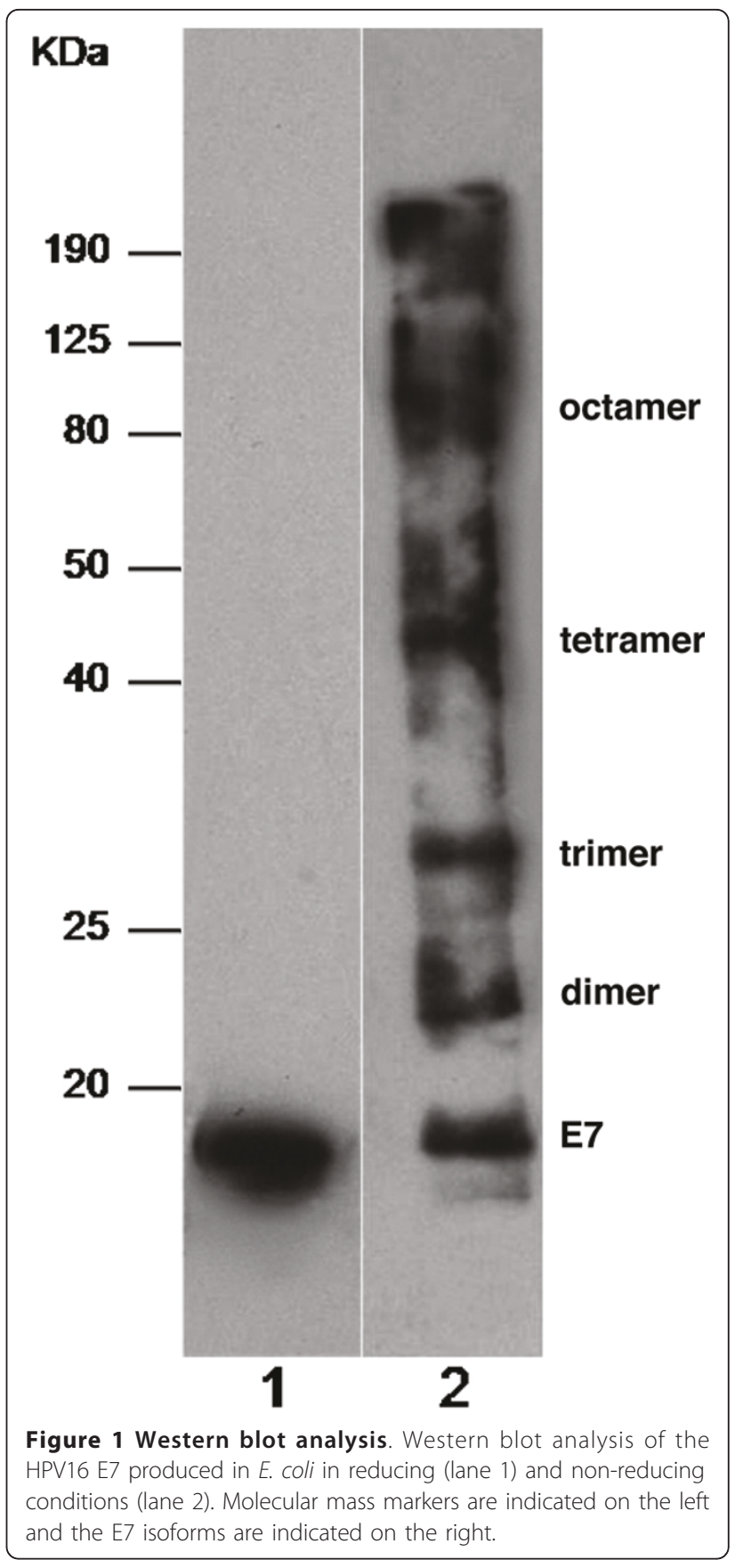

HPV16 E7 contains a Zinc finger-like domain that binds the metal even when the protein is expressed in E. coli $[10,11]$. Since the E7 purification protocol used does not employ either chelating agents or Zinc salts, several E7 samples were analysed for $\mathrm{Zn}^{++}$content by high resolution mass spectrometry (HR-ICP-MS). The recombinant GST protein was used as a control. The $\mathrm{Zn}^{++}$ion concentration in the E7 preparations was 1.13 $\mu \mathrm{g} / \mathrm{g} \pm 0.10$ while GST showed only trace level of $\mathrm{Zn}^{++}$ $(0.19 \mu \mathrm{g} / \mathrm{g} \pm 0.02)$. The metal/protein ratio was 


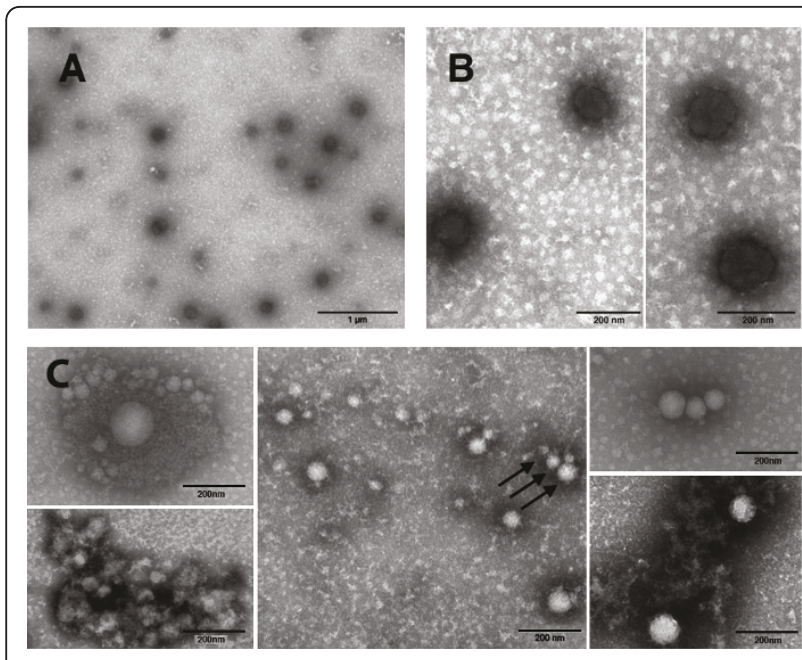

Figure 2 Electron micrographs. Electron micrographs of the negatively stained E7 preparation samples. Panel A. E7 particles of different shape and size. Panel B. Spheroidal microaggregates of compact aspect. Panel C. Highly structured E7-particles of different size are indicated by arrows. The magnitude scale bars are indicated.

calculated to be 0.19 , therefore only about $19 \%$ of the E7 molecules were bound to $\mathrm{Zn}^{++}$.

\section{Induction of tumour-protective immunity}

To investigate if this E. coli-derived HPV16-E7 preparation, administrated without adjuvant, was able to induce a tumour-protective immunity, groups of mice were inoculated with $10 \mu \mathrm{g}$ of protein per mouse, 1,2 or 3 times, at one week intervals. As a control group, mice were inoculated with a saline solution (naïve group). Two weeks after the last immunization, some of the animals were bled and killed to analyse the immune response, in vitro. The remaining animals were challenged with the TC-1 tumour cells and the inhibition of tumour growth in these mice was monitored for 2 months.

To quantify the humoral immune response and to compare the results obtained from several animal groups, the sera from the animals of each group were pooled, then sequentially diluted to determine the antibody titres by end-point dilution in an E7-based ELISA [30]. The anti-E7 IgG titre was 1:200 after a single immunization and progressively increased in mice immunized 2 and 3 times, reaching 1:8000 and 1:16000 respectively. The presence of IgM and IgA was analysed in comparison with the IgG and the results are shown in Figure 3. In panel A, the anti-E7 specific antibodies of mice immunised 1, 2 or 3 times either with E7 or a saline solution are shown. The sera show an increase of anti-E7 specific IgG already after the second protein dose; IgMs were detected only after the third E7-dose,

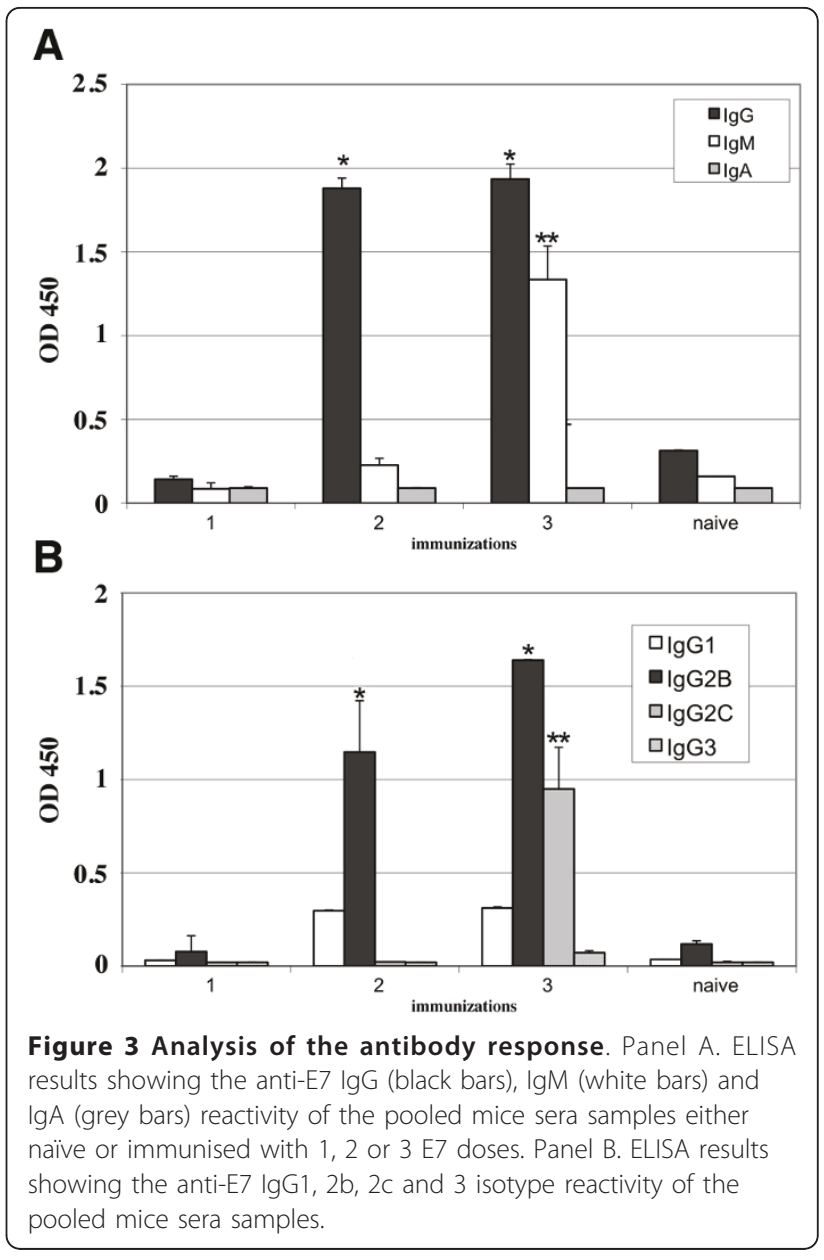

while IgAs were never detectable. Animals inoculated with 3 doses of saline solution did not show any E7 specific antibody response (naïve, panel A).

The therapeutic effector functions of antibodies depend on their class and subclasses [37]. In order to better evaluate the E7-specific humoral immune response, the anti-E7 specific IgG1, IgG2b, IgG2c (IgG2a) and IgG3 antibody subclasses were also determined. The results, shown in Figure 3, panel B, show that the IgG2b level was significant after the second immunization while the level of IgG2c was significant only after the third immunization. The level of IgG1 was not significant and IgG3s were undetectable. This anti-E7 IgG isotype profile indicates that the immune response induced in vaccinated mice is a mixed Th1/ Th2 type.

To analyse the induction of the cell-mediated immune response in mice after 1, 2 or 3 doses of the E7 preparation, T-enriched splenocytes from mice of the same immunization group were stimulated in vitro, with the E7-specific CTL peptides and processed for T cell proliferation and $\gamma$-IFN ELISPOT assays. Splenocytes from 
naïve mice were pulsed with an unrelated mixture of peptides used as control. The results are shown in Figure 4. Splenocytes from mice immunised with 2 and 3 doses of E7 showed a high Stimulation Index (SI) suggesting that specific $\mathrm{T}$ clone selection occurred after E7 peptide stimulation. Splenocytes from naïve mice and from mice immunised once showed non-significant SI. Conversely, in the $\gamma$-IFN ELISPOT assay (panel B) only the splenocytes of mice that received 3 E7 doses, stimulated with the E7-specific CTL peptides, showed a significant level of E7-specific $\gamma$-IFN producing cells (panel B, 3).

To evaluate the efficacy of the E7 preparation as inductor of anti-tumour immunity, the mice immunised with 1, 2 or 3 doses of E7 were challenged with the TC1 tumour cells, and the tumour growth was monitored for two months after the challenge. The results are shown in Figure 5. Mice vaccinated with three doses of E7 particles were fully protected from tumour growth. Only $40 \%$ of the mice immunised with 2 doses of E7 were tumour free, whereas the mice immunised with 1 dose and the naïve mice developed a palpable tumour within 4 weeks of tumour-monitoring, after the challenge with TC-1 cells.

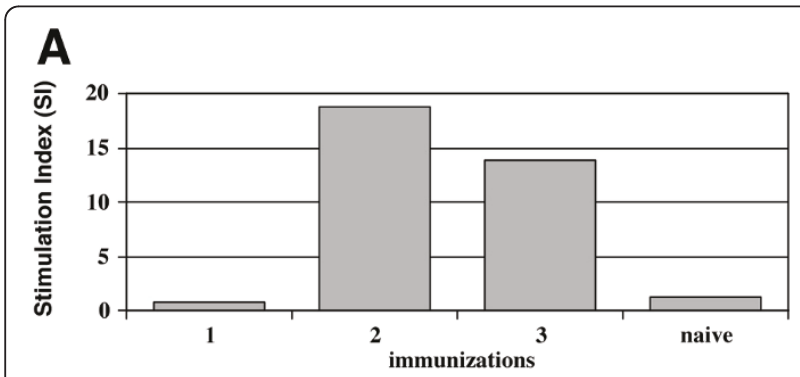

B

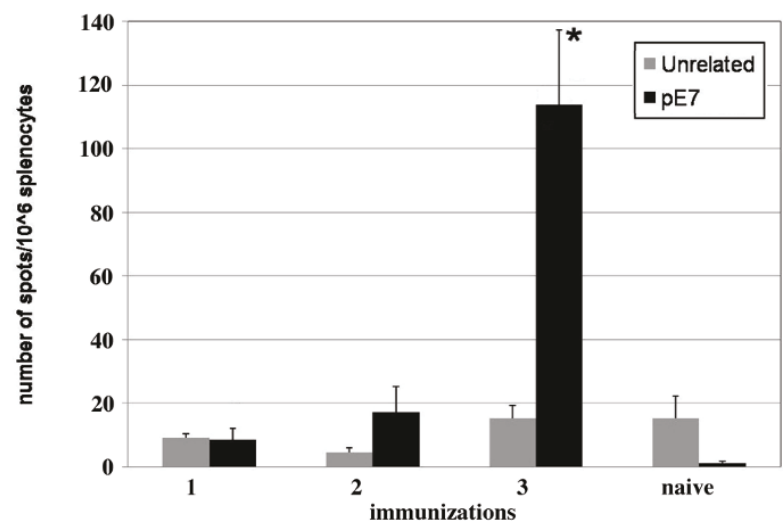

Figure 4 Analysis of the cell-mediated immune response. Panel A. T cell proliferative response of $\mathrm{C} 57 \mathrm{BL} / 6$ naïve and mice immunised with 1, $2 \circ 3$ E7 doses. Panel B. IFN $\gamma$ - secreting cells from naive mice and mice immunised with 1, 2 o 3 E7 doses. Cells were stimulated with two CTL E7 peptides (black bars) or with an unrelated peptide (grey bars).

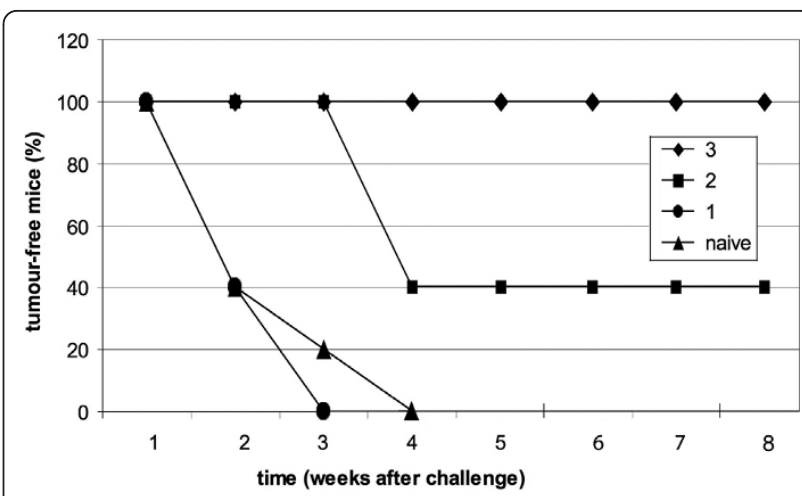

Figure $\mathbf{5}$ Tumour protection experiment. Mice either naïve or vaccinated with 1, 2 and 3 doses of E7 were challenged with $1 \times$ $10^{5} \mathrm{TC}-1$ tumour cells and the tumour growth was monitored weekly. The percentages of mice without tumour are indicated.

\section{Discussion}

This study reports the induction in mice of a tumourprotective immunity using an E. coli-derived HPV-E7 preparation containing particles. E7 has been intensively studied for many years. However, this is the first time, to our knowledge, that a particulate form of E7 has been used as an immunogen and proposed as a nonadjuvated vaccine. Our results show that, the tumourprotective immunity in the mouse $\mathrm{TC} 1 / \mathrm{C} 57 \mathrm{BL} / 6$ tumour model correlates to the elicited E7-specific $\mathrm{T}$ cell response, and to the IgG isotype switching (IgG2b and IgG2c).

Previous studies on bacterial-derived E7 showed that Zinc has a role in E7 particle formation. Chinami et al. [20] obtained E7 nanoparticles using Zinc acetate both in culture medium and purification buffers. On the contrary, Alonso et al. [27] obtained well defined-E7 oligomers after EDTA chelation of Zinc. For our E7 preparations, neither the culture medium nor the purification buffers contained Zinc salts. The analysis of the Zinc content in our protein preparation indicates that only $19 \%$ of E7 binds the metal, suggesting that several forms of particles could be generated from the bacterial-derived E7. The metal does not seem important for the formation of our E7 micro- and nanoparticles, at least not in the experimental conditions used here. We did not increase the $\mathrm{Zn}^{++}$content in the E7 preparation used as immunogen in mice, considering that while $\mathrm{Zn}^{++}$is an essential mineral in eukaryotic systems, a high quantity of the metal is also toxic [38]. When Zinc was removed from the E7 preparation by dialysis in the presence of $1 \mathrm{mM}$ EDTA, the protein's solubility decreased resulting in salting out of E7 as large aggregates without forming micro- and nanoparticles, as observed by EM (data not shown).

As the aim was to obtain a highly immunogenic E7 preparation, we did not focus on obtaining identical 
particles, considering that particles of different size can be taken up by different types of antigen presenting cells, such as dendritic cells, macrophages and polymorphonuclear leukocytes, sustaining a more potent immune response $[39,40]$. However, we standardized the different preparations by semi-quantitative counting of particles on EM micrographs (not shown).

The immunogenicity of E. coli-derived E7 fused, through the N-terminus, to either HPV16 E6 or GST, was also investigated in mice. An antigen-specific immune response of Th2 polarity was obtained when the fusion proteins were administered to mice without adjuvant (data not shown). However, we were unable to observe the typical micro- and nanoparticles in these E7-fusion proteins prepared from E. coli (data not shown).

Recently, the cytosolic accumulation of E7-oligomers shown in HPV16 cervical cancer cell lines and in clinical samples by indirect methods, supports a new hypothesis regarding the presence of E7 isoforms and their role in different cell compartments [41-43]. As keratinocytes display antigen-presenting cell features [44], the presence of E7 in different aggregation forms and cell compartments could affect E7 processing and presentation by MHC I and II molecules, determining both the strength and quality of the host's anti-HPV immunity.

More studies on recombinant E. coli-derived E7, assembled in different forms, would contribute to explaining how the different branches of the immune system in the HPV16 mouse tumour model are stimulated. Significant differences exist between the HPV16 mouse tumour model and human HPV16-dependent diseases. However, studies on IgG subclasses and their Fc $\gamma \mathrm{R}$ receptors between mouse and human are comparable (37). We believe that HPV16 E7 immunogenicity studies in mouse will provide insights into the understanding of the protective immunity against human HPV16 infections as well.

The commercial preventive HPV vaccines have high production costs which has made widespread vaccination programs still not possible. Recently, new combined preventive and therapeutic HPV vaccines produced in $E$. coli have been described [45-47] and the data presented here suggests a possible use of E. coli-derived E7 in particle form in subunit vaccines. The $E$. coli expressed proteins represent a well-studied and cost-effective means for the production of vaccines. These methods require reduced time, costs, labour and can be easily scaled up in industrial-scale productions. A generation of new low-cost HPV vaccines could represent the only possibility for women living in developing countries to gain access to HPV vaccination programs to prevent or treat pre-cancerous lesions and cancer.

\section{Conclusions}

The paper describes, for the first time, the use of recombinant HPV16 E7, assembled in vitro into particulate form, to induce protective immunity against a HPV16-related tumour in an HPV16 mouse tumour model. Data show that E7 particles, used without adjuvant, are excellent stimulators of the immune system. In C57BL/6 mice, the E7 preparation induces anti-tumour immunity sustained by both humoral and cell-mediated immune responses. This E7 protein (derived from Escherichia coli) without adjuvant could represent, along with the recently proposed $E$. coliderived HPV antigens [45-47], a low cost constituent for the development of a new generation of HPV16 vaccines, which combine prophylactic and therapeutic activities.

\section{Acknowledgements and Funding}

We wish to thank Professor T.C. Wu for kindly providing the TC-1 cell line, Dr Jill Marturano for reading and discussing this manuscript, Mr Andrea Giacomelli and Mrs Monica Gabrielli of the MIPI-animal care unit, and Mr Valter Tranquilli for assistance in computer artwork. The work was supported by the Project on Oncology (2007-2010) of the Italian Ministry of Health.

\section{Author details}

1 Department of Infectious Parasitic and Immune-mediated Diseases, Istituto Superiore di Sanità, Viale Regina Elena 299, 00161 Rome, Italy. ${ }^{2}$ Department of Technology and Health, Istituto Superiore di Sanità, Viale Regina Elena 299, 00161 Rome, Italy. ${ }^{3}$ Environment and Primary Prevention Department, Istituto Superiore di Sanità, Viale Regina Elena 299, 00161 Rome, Italy.

\section{Authors' contributions}

LP carried out the biochemical and immunological assays, made contribution to the analysis and interpretation of the data and helped to draft the manuscript; MGA carried out the EM analysis and made contribution in data analysis; AC performed the experiments with the animals. SC carried out the mass spectrometry experiments; FB made contribution in data analysis; CG made contribution to the analysis and interpretation of the data, in critical revision of the manuscript and in acquisition of funding. PDB conceived and designed the study, analysed and interpreted the data and drafted the manuscript. All authors read and approved the final manuscript.

\section{Authors' information}

LP'S present address: Istituto Nazionale Malattie Infettive "L. Spallanzani", Rome. CG 's present e-mail: ros.giorgi@gmail.com.

\section{Competing interest}

The authors declare that they have no competing interests.

Received: 21 December 2010 Accepted: 18 May 2011

Published: 18 May 2011

\section{References}

1. Zur Hausen H: Papillomavirus infections: A Major Cause of Human Cancer. In Infections Causing Human Cancer. Edited by: Harald zur Hausen. Weinheim: WILEY-VCH Verlag GmbH 2006:145-243.

2. Wise-Draper TM, Wells SI: Papillomavirus E6 and E7 proteins and their cellular targets. Frontiers in Bioscience 2008, 13:1003-1017.

3. McLaughlin-Drubin ME, Münger K: The human papillomavirus E7 oncoprotein. Virology 2009, 384:335-344.

4. Ghittoni R, Accardi R, Hasan U, Gheit T, Sylla B, Tommasino M: The biological properties of E6 and E7 oncoproteins from human papillomaviruses. Virus Genes 2009, 40:1-13

5. Alonso LG, Smal C, Garcia-Alai MM, Chemes L, Salame M, de Prat-Gay G: Chaperone holdase activity of human papillomavirus E7 oncoprotein Biochemistry 2006, 45:657-667. 
6. Coulie PG, Weynants P, Lehmann F, Herman J, Brichard V, Wölfel T, Van Pel A, De Plaen E, Brasseur F, Boon T: Genes coding for tumor antigens recognized by human cytolytic T lymphocytes. J Immunother Emphasis Tumor Immunol 1993, 14:104-109.

7. Hellner K, Münger K: Human Papillomaviruses As Therapeutic Targets in Human Cancer. J Clin Oncol 2011 [http://jco.ascopubs.org/content/29/13/ 1785.full?sid=23bbb452-d962-4f56-acaa-4a40c9093c56], Published online ahead of print on Jan 10 at.

8. Su JH, Wu A, Scotney E, Ma B, Monie A, Hung CF, Wu TC: Immunotherapy for cervical cancer: Research status and clinical potential. BioDrugs 2010, 24:109-129.

9. van der Burg SH, Melief $\mathrm{CJ}$ : Therapeutic vaccination against human papillomavirus induced malignancies. Curr Opin Immunol 2011, 23:1-6.

10. Barbosa MS, Lowy DR, Schiller JT: Papillomavirus polypeptides E6 and E7 are zinc-binding proteins. J Virol 1989, 63:1404-1407.

11. McIntyre MC, Frattini MG, Grossmon S, Laimons LA: Human papillomavirus type $18 \mathrm{E} 7$ protein requires intact Cys-X-X-Cys motifs for zinc binding, dimerization, and transformation but not for Rb binding. J Virol 1993, 67:3142-3150

12. Pahel G, Aulabaugh A, Short SA, Barnes JA, Painter GR, Ray P, Phelps WC: Structural and functional characterization of the HPV16 E7 protein expressed in bacteria. J Biol Chem 1993, 68:26018-26025

13. Alonso LG, Garcia-Alai MM, Nadra AD, Lapena AN, Almeida FL, Gualfetti P, de Prat-Gay G: High-risk (HPV16) human papillomavirus E7 oncoprotein is highly stable and extended, with conformational transitions that could explain its multiple cellular binding partners. Biochemistry 2002, 41:10510-10518.

14. Patrick DR, Zhang K, Defeo-Jones D, Vuocolo GR, Maigetter RZ, Sardana MK, Oliff A, Heimbrook DC: Characterization of functional HPV-16 E7 protein produced in Escherichia coli. J Biol Chem 1992, 267:6910-6915.

15. Sato H, Watanabe S, Furuno A, Yoshiike K: Human papillomavirus type 16 E7 protein expressed in Escherichia coli and monkey COS-1 cells: immunofluorescence detection of the nuclear E7 protein. Virology 1989, 170:311-315.

16. Tommasino M, Contorni M, Scarlato V, Bugnoli M, Maundrell K, Cavalieri F: Synthesis, phosphorylation, and nuclear localization of human papillomavirus E7 protein in Schizosaccharomyces pombe. Gene 1990, 93:265-270.

17. Carter JJ, Yaegashi N, Jenison SA, Galloway DA: Expression of human papillomavirus proteins in yeast Saccharomyces cerevisiae. Virology 1991, 182:513-521.

18. Patrick DR, Zhang K, Defeo-Jones D, Vuocolo GR, Maigetter RZ, Sardana MK, Oliff A, Heimbrook DC: Characterization of functional HPV-16 E7 protein produced in Escherichia coli. J Biol Chem 1992, 267:6910-6915.

19. Park DS, Selvey LA, Kelsall SR, Frazer $\| H$ : Human papillomavirus type 16 E6, E7 and L1 and type 18 E7 proteins produced by recombinant baculoviruses. J Virol Methods 1993, 45:303-318.

20. Chinami M, Sasaki S, Hachiya N, Yuge K, Ohsugi T, Maeda H, Shingu M: Functional oligomerization of purified human papillomavirus types 16 and 6b E7 proteins expressed in Escherichia coli. J Gen Virol 1994, 75:277-281.

21. Clemens KE, Brent R, Gyuris J, Münger K: Dimerization of the human papillomavirus E7 oncoprotein in vivo. Virology 1995, 214:289-293.

22. Zwerschke W, Joswig S, Jansen-Dürr P: Identification of domains required for transcriptional activation and protein dimerization in the human papillomavirus type-16 E7 protein. Oncogene 1996, 12:213-220.

23. Clements A, Johnston K, Mazzarelli JM, Ricciardi RP, Marmorstein R: Oligomerization properties of the viral oncoproteins adenovirus E1A and human papillomavirus E7 and their complexes with the retinoblastoma protein. Biochemistry 2000, 39:16033-16045.

24. Mirecka EA, Rudolph R, Hey T: Expression and purification of His-tagged HPV16 E7 protein active in pRb binding. Protein Expr Purif 2006, 48:281-291.

25. Franconi R, Di Bonito P, Dibello F, Accardi L, Muller A, Cirilli A, Simeone P, Donà G, Venuti A, Giorgi C: Plant-derived human papillomavirus 16 E7 oncoprotein induces immune response and specific tumor protection. Cancer Research 2002, 62:3654-3658.

26. Massa S, Simeone P, Muller A, Benvenuto E, Venuti A, Franconi R: Antitumor activity of DNA vaccines based on the human papillomavirus-
16 E7 protein genetically fused to a plant virus coat protein. Hum Gene Ther 2008, 19:354-364.

27. Alonso LG, García-Alai MM, Smal C, Centeno JM, lacono R, Castaño E, Gualfetti P, de Prat-Gay G: The HPV16 E7 viral oncoprotein self-assembles into defined spherical oligomers. Biochemistry 2004, 43:3310-3317.

28. Di Lonardo A, Marcante ML, Poggiali F, Venuti A: HPV 16 E7 antibody levels in cervical cancer patients: before and after treatment. J Med Virol 1998, 54:192-195.

29. Waterboer $T$, Sehr $P$, Michael KM, Franceschi S, Nieland JD, Joos TO, Templin MF, Pawlita M: Multiplex human papillomavirus serology based on in situ-purified glutathione S-transferase fusion proteins. Clin Chem 2005, 51:1845-1853.

30. Di Bonito P, Grasso F, Mochi S, Accardi L, Donà MG, Branca M, Costa S, Mariani L, Agarossi A, Ciotti M, Syrjänen K, Giorgi C: Serum antibody response to Human papillomavirus (HPV) infections detected by a novel ELISA technique based on denatured recombinant HPV16 L1, L2, E4, E6 and E7 proteins. Infect Agent Cancer 2006, 8:1-6.

31. Ferguson M, Heath $A$, Johnes $S$, Pagliusi $S$, Dillner J: Results of the first WHO international collaborative study on the standardization of the detection of antibodies to human papillomaviruses. Int J Cancer 2006 118:1508-1514

32. Lin KY, Guarnieri FG, Staveley-O'Carroll KF, Levitsky HI, August JT, Pardoll DM, Wu TC: Treatment of established tumors with a novel vaccine that enhances major histocompatibility class II presentation of tumor antigen. Cancer Res 1996, 56:21-26.

33. Ramachandra L, Simmons D, Harding CV: MHC molecules and microbial antigen processing in phagosomes. Curr Opin Immunol 2009, 21:98-104.

34. Di Bonito P, Grasso F, Mangino G, Massa S, Illiano E, Franconi R, FanalesBelasio E, Falchi M, Affabris E, Giorgi C: Immunomodulatory activity of a plant extract containing human papillomavirus $16-\mathrm{E} 7$ protein in human monocyte-derived dendritic cells. Int J Immunopathol Pharmacol 2009, 22:967-978.

35. Di Bonito P, Grasso F, Mochi S, Petrone L, Fanales-Belasio E, Mei A, Cesolini A, Laconi G, Conrad H, Bernhard H, Dembek CJ, Cosma A, Santini SM, Lapenta C, Donati S, Muratori C, Giorgi C, Federico M: Antitumor CD8+ T cell immunity elicited by HIV-1-based virus-like particles incorporating HPV-16 E7 protein. Virology 2009, 395:45-55.

36. Bauer S, Heeg K, Wagner H, Lipford GB: Identification of $\mathrm{H}-2 \mathrm{~Kb}$ binding and immunogenic peptides from human papilloma virus tumour antigens E6 and E7. Scand J Immunol 1995, 42:317-323.

37. Nimmerjahn F, Ravetch JV: Fcgamma receptors as regulators of immune responses. Nat Rev Immunol 2008, 8:34-47.

38. John E, Laskow TC, Buchser WJ, Pitt BR, Basse PH, Butterfield LH, Kalinski P, Lotze MT: Zinc in innate and adaptive tumor immunity. J Transl Med 2010, 8:118.

39. Nandedkar TD: Nanovaccines: recent developments in vaccination. $J$ Biosci 2009, 34:995-1003.

40. Oyewumi MO, Kumar A, Cui Z: Nano-microparticles as immune adjuvants: correlating particle sizes and the resultant immune responses. Expert Rev Vaccines 2010, 9:1095-1107.

41. Dantur K, Alonso L, Castaño E, Morelli L, Centeno-Crowley JM, Vighi S, de Prat-Gay G: Cytosolic accumulation of HPV16 E7 oligomers supports different transformation routes for the prototypic viral oncoprotein: the amyloid-cancer connection. Int J Cancer 2009, 125:1902-1911.

42. Valdovinos-Torres H, Orozco-Morales M, Pedroza-Saavedra A, PadillaNoriega L, Esquivel-Guadarrama F, Gutierrez-Xicotencatl L: Different Isoforms of HPV-16 E7 Protein are Present in Cytoplasm and Nucleus. Open Virol J 2008, 2:15-23.

43. Knapp AA, McManus PM, Bockstall K, Moroianu J: Identification of the nuclear localization and export signals of high risk HPV16 E7 oncoprotein. Virology 2009, 383:60-68

44. Nestle FO, Di Meglio P, Qin JZ, Nickoloff BJ: Skin immune sentinels in health and disease. Nat Rev Immunol 2009, 8:679-691.

45. Schädlich L, Senger T, Kirschning CJ, Müller M, Gissmann L: Refining HPV $16 \mathrm{~L} 1$ purification from $E$. coli: reducing endotoxin contaminations and their impact on immunogenicity. Vaccine 2009, 27:1511-1522.

46. Bian T, Wang Y, Lu Z, Ye Z, Zhao L, Ren J, Zhang H, Ruan L, Tian H: Human papillomavirus type $16 \mathrm{~L} 1 \mathrm{E} 7$ chimeric capsomeres have prophylactic 
and therapeutic efficacy against papillomavirus in mice. Mol Cancer Ther 2008, 7:1329-1335.

47. Rubio I, Bolchi A, Moretto N, Canali E, Gissmann L, Tommasino M: Potent anti-HPV immune responses induced by tandem repeats of the HPV16 L2 (20-38) peptide displayed on bacterial thioredoxin. Vaccine 2009, 27:1949-1956.

doi:10.1186/1479-5876-9-69

Cite this article as: Petrone et al:: Recombinant HPV16 E7 assembled into particles induces an immune response and specific tumour protection administered without adjuvant in an animal model. Journal of Translational Medicine 2011 9:69.

Submit your next manuscript to BioMed Central and take full advantage of:

- Convenient online submission

- Thorough peer review

- No space constraints or color figure charges

- Immediate publication on acceptance

- Inclusion in PubMed, CAS, Scopus and Google Scholar

- Research which is freely available for redistribution

Submit your manuscript at www.biomedcentral.com/submit
() Biomed Central 